\title{
Nicotine replacement therapy: a treatment angle for oral diagnostician
}

\begin{abstract}
As an oral diagnostician, many of our patients we come across are mostly the potentially malignant disorder cases. Either it might be leukoplakia, nicotina stomatitis, oral submucous fibrosis, tobacco pouch keratosis. In each of this cases where habits are the prime factor for occurrence of the lesions intraorally, the first line of treatment is cessation of the habits. But practically speaking, we don't spend much time about the cessation of the habits. As an oral diagnostician, it is our duty to motivate and educate the patient about the evil effects of the deleterious habits and need to follow up the patient and guide him to quit the habits. This article intends to highlight about one of the methods to stop the deleterious habit of smoking that is nicotine replacement therapy and therewith preventing the transformation of potentially malignant disorders into oral cancer.
\end{abstract}

Keywords: nicotine replacement therapy, potentially malignant disorders, oral cancer, smoking
Volume 10 Issue 6 - 2018

\author{
Anusha Rangare Lakshman,' Nilofer Halim,' \\ Chaithra Kalkur,' Amithash RL, ${ }^{2}$ Apoorva \\ Mithrananda, ${ }^{3}$ Sham Kishor Kannepady ${ }^{4}$ \\ 'Department of Oral Medicine and Radiology, Century \\ International Institute of Dental Science and Research Centre, \\ India \\ ${ }^{2}$ MBBS, MS Orthopaedics, Consultant Orthopaedic Surgeon, \\ India \\ ${ }^{3}$ MBBS, MS Opthalmology, Consultant Opthalmologist, India \\ ${ }^{4}$ Senior Lecturer, Division of Oral Diagnostics and Surgical \\ Sciences, International Medical University, India
}

\begin{abstract}
Correspondence: Anusha Rangare Lakshman, M.D.S, Reader, Department of Oral Medicine and Radiology, Century International Institute of Dental Science and Research Centre, Poinachi, Kasaragod-67I54I, Kerala, India, Email dr.anushavl@gmail.com
\end{abstract}

Received: July 23, 2018 | Published: November 23, 2018

\section{Introduction}

Oral cancers have become very common tumors among the people mainly because of the tobacco habits addiction. Epidemiological studies show that the risk of developing oral cancer is five to nine times greater for smokers than for nonsmokers, and this risk may increase to as much as 17 times greater for extremely heavy smokers of 80 or more cigarettes per day. ${ }^{1}$ As an oral diagnostician, we come across day to day at least one lesion which is habit associated, it might be either smoking, smokeless tobacoo or gutka or pan chewing. In spite of educating the patients about the ill effects of all this deleterious habits, patient won't quit the habits. So it is important for us find some alternative method to motivate and help the patient to stop habits. Nicotine replacement therapy (NRT) is one of the methods to quit the habit of smoking. This term is heard long time back but still we feel personally, the most of the general dentists are unaware about NRT and its dosing. We have tried to briefly enlighten about the NRT, its mechanism, various modes and its dosages which might guide the general dentists to use NRT regularly in their private practice and thereby prevent the transformation of premalignant lesions into oral carcinoma.

\section{Ingredients of tobacco}

Tobacco and its products are extremely toxic. Its smoke has at least 250 chemicals out of 7000 , which are harmful and 69 are known carcinogens. Such as Stearic acid, Butane, Methanol, Acetic acid, Hexamine, Methane, Cadmium, Arsenic, Toluene, Ammonia, Carbon monoxide, and finally the main culprit, Nicotine, the addictive product of the tobacco, the role of which cannot be overlooked. Now talking about the smokeless form, 31 carcinogens have been identified till date. Like tobacco-specific nitrosamines, polycyclic aromatic hydrocarbons (PAHs), benzo $[a]$ pyrene, urethane, formaldehyde, acetaldehyde, nickel, arsenic and chromium. ${ }^{2}$

\section{Tobacco associated oral lesions}

The toxic components of tobacco either as smoke or chewing form, causes damage to the oral mucosa. The free radicals produced from these products penetrate the epithelium and causes damage to the oral structures. The heat generated by the smoking habit also causes damage to these oral structures. These even stimulate the melanocytes. The following Table 1 shows the list of oral lesions associated with tobacco habits.

Table I Shows the list of oral lesions associated with tobacco habits

\begin{tabular}{llll}
\hline SI no: & Oral lesion & Habits & Most commom Sites \\
\hline 1 & Smoker's melanosis & Smoking & Buccal mucosa + labial mucosa + gingiva \\
2 & Nicotina stomatitis & Smoking & Palate \\
3 & Tobacco pouch keratosis & Smokeless tobacco & Vestibule \\
4 & Leukoplakia & Smoking + smokeless tobacco & Buccal mucosa + labial mucosa \\
5 & Oral submucous fibrosis & smokeless tobacco & Buccal mucosa + labial mucosa + palate + uvula \\
6 & Oral cancer & Smoking + smokeless tobacco & Buccal mucosa + alveolar mucosa + tongue \\
\hline
\end{tabular}




\section{The culprit: nicotine}

Nicotine is the main active component of tobacco products leading to its addiction. ${ }^{3,4}$ It is the main alkaloid and the principal modulator with psychopharmacological effects. ${ }^{5}$ So, if we need to help the patient to quit the tobacco habits, we should have thorough knowledge about the neurochemical and psychopharmacological effects of nicotine. ${ }^{6}$

\section{What is nicotine replacement therapy (NRT)?}

NRT is replacing the harmful nicotine with the 'clean' or therapeutic nicotine. The 'clean' or 'therapeutic' nicotine is referred to as nicotine that is not associated with the harmful constituents found in tobacco smoke. So this NRT targets the patient in two aspects, firstly it helps in de-addiction, secondly the emotional aspects associated with it.?

\section{Mechanism of action}

NRT is assumed to help in release of neurochemical, dopamine from the nucleus accumbens, by stimulating the nicotinic receptors present in the ventral tegmental area of the brain. Not only it is effective centrally but its peripheral action also helps in reduction in nicotine withdrawal symptoms in regular smokers who abstain from smoking. ${ }^{8}$

It will not help to completely stop the habits, but helps to reduce to certain extent mainly because of the compromised nicotine delivery system. That means, none of the different delivery systems cannot reach high levels of nicotine in the arteries which is easily achieved during cigarette smoking. For medicinal products such as nasal spray or gum, inhalator, sublingual tablet, or lozenge achieve lower levels over a period of minutes and for transdermal patches, it's in hours.

\section{Different forms of NRT:}

The different NRT products have been summarized in Table 2 with the dose, its uses, adverse effects and the precautions. Various available forms includes: gum, transdermal patch, nasal spray, oral inhaler, and tablet. ${ }^{9}$

Table 2 Different formulations of NRT.6,9,13,14

\begin{tabular}{|c|c|c|c|c|c|}
\hline $\begin{array}{l}\text { NRT } \\
\text { formulations }\end{array}$ & Available doses & Cautions / warning & Uses & Adverse events & Availability \\
\hline $\begin{array}{l}\text { Transdermal } \\
\text { patches }\end{array}$ & $\begin{array}{l}5 \mathrm{mg}, 10 \mathrm{mg}, 15 \mathrm{mg} \text { doses } \\
\text { worn over } 16 \text { hours } 7 \mathrm{mg}, \mathrm{I} 4 \\
\mathrm{mg}, 21 \mathrm{mg} \text { doses worn } \\
\text { over } 24 \text { hours }\end{array}$ & $\begin{array}{l}\text { For smokers with insomnia } \\
\text { and other sleep-related } \\
\text { adverse events, the patches } \\
\text { should be removed before } \\
\text { bedtime. }\end{array}$ & $\begin{array}{l}\text { One daily on clean, } \\
\text { unbroken skin; remove } \\
\text { before bed } \\
\text { ( } 16 \text { h patch) or next } \\
\text { morning ( } 24 \text { h); new } \\
\text { patch, fresh site }\end{array}$ & $\begin{array}{l}\text { Local skin } \\
\text { reaction Insomnia }\end{array}$ & $\begin{array}{l}\text { US FDA } \\
\text { (OTC), } \\
\text { MHRA (OTC) }\end{array}$ \\
\hline Chewing gum & $2 \mathrm{mg}$ and $4 \mathrm{mg}$ doses & $\begin{array}{l}\text { Temporomandibular } \\
\text { joint disease Caution with } \\
\text { dentures Do not eat or drink } \\
\text { I } 5 \text { min before or } \\
\text { during use }\end{array}$ & $\begin{array}{l}\text { Chew gum until taste } \\
\text { is strong, then rest gum } \\
\text { between gum and cheek; } \\
\text { chew again when taste } \\
\text { has faded. Try not to } \\
\text { swallow excessively. }\end{array}$ & $\begin{array}{l}\text { Mouth soreness, } \\
\text { Hiccups, } \\
\text { Dyspepsia and } \\
\text { Jaw ache }\end{array}$ & $\begin{array}{l}\text { US FDA } \\
\text { (OTC) } \\
\text { MHRA } \\
\text { (OTC) }\end{array}$ \\
\hline Lozenge & Img, $2 \mathrm{mg}$ and $4 \mathrm{mg}$ doses & $\begin{array}{l}\text { Do not eat or drink } \\
\text { I } 5 \text { minutes before or } \\
\text { during use One lozenge at a } \\
\text { time Limit } 20 \text { in } 24 \text { hours }\end{array}$ & $\begin{array}{l}\text { Allow to dissolve in } \\
\text { mouth (about } 20-30 \\
\text { minutes), moving from } \\
\text { side-to-side from time-to- } \\
\text { time. Try } \\
\text { not to swallow } \\
\text { excessively. Do not chew } \\
\text { or swallow whole }\end{array}$ & $\begin{array}{l}\text { Nausea/ } \\
\text { Heartburn }\end{array}$ & $\begin{array}{l}\text { US FDA } \\
\text { (OTC) } \\
\text { MHRA } \\
\text { (OTC) }\end{array}$ \\
\hline $\begin{array}{l}\text { Nicotine } \\
\text { inhalation } \\
\text { Cartridge plus } \\
\text { mouthpiece }\end{array}$ & Cartridge containing $10 \mathrm{mg}$ & $\begin{array}{l}\text { May irritate } \\
\text { mouth/throat at first }\end{array}$ & $\begin{array}{l}\text { Spray into the mouth, } \\
\text { avoiding the lips. Do not } \\
\text { inhale while } \\
\text { spraying. Use when } \\
\text { cigarettes would usually } \\
\text { be smoked or } \\
\text { if cravings emerge. } \\
\text { Do not swallow for a } \\
\text { few seconds after } \\
\text { spraying }\end{array}$ & $\begin{array}{l}\text { Local } \\
\text { irritation } \\
\text { of mouth } \\
\text { and } \\
\text { throat }\end{array}$ & $\begin{array}{l}\text { US FDA } \\
(\mathrm{Rx}) \\
\text { MHRA (Rx) }\end{array}$ \\
\hline $\begin{array}{l}\text { Nicotine } \\
\text { metered nasal } \\
\text { spray }\end{array}$ & $0.5 \mathrm{mg}$ dose/spray & $\begin{array}{l}\text { Not for patients with } \\
\text { asthma } \\
\text { May cause } \\
\text { dependence }\end{array}$ & $\begin{array}{l}\text { Take shallow puffs } \\
\text { approximately every } 2 \\
\text { seconds or } \\
\text { alternatively take four } \\
\text { puffs every minute. } \\
\text { Continue for up to } 30 \\
\text { minutes. }\end{array}$ & $\begin{array}{l}\text { Nasal } \\
\text { irritation }\end{array}$ & $\begin{array}{l}\text { US FDA } \\
(\mathrm{Rx}) \\
\text { MHRA (Rx) }\end{array}$ \\
\hline
\end{tabular}


Table Continued

\begin{tabular}{|c|c|c|c|c|c|}
\hline $\begin{array}{l}\text { NRT } \\
\text { formulations }\end{array}$ & Available doses & Cautions / warning & Uses & Adverse events & Availability \\
\hline $\begin{array}{l}\text { Electronic } \\
\text { cigarette }\end{array}$ & & May cause dependence & $\begin{array}{l}\text { E-Cigarette vapor is } \\
\text { drawn very slowly into } \\
\text { mouth, then held there } \\
\text { for a second or two. Then, } \\
\text { it can be } \\
\text { inhaled if desired. } \\
\text { The vapor is then } \\
\text { expelled through the } \\
\text { mouth or nose. }\end{array}$ & $\begin{array}{l}\text { Mouth and } \\
\text { airway } \\
\text { irritation, } \\
\text { chest pain, } \\
\text { and } \\
\text { palpitation } \\
(15,16)\end{array}$ & $\begin{array}{l}\text { Untill now, it } \\
\text { is not } \\
\text { approved by } \\
\text { any agency }\end{array}$ \\
\hline $\begin{array}{l}\text { High dose } \\
\text { nicotine } \\
\text { patches }^{17}\end{array}$ & $\geq 42 \mathrm{mg}$ daily & $\begin{array}{l}\text { Irritation at the patch } \\
\text { application site. } \\
\text { Sleep disturbances }\end{array}$ & $\begin{array}{l}\text { One daily on clean, } \\
\text { unbroken } \\
\text { skin; remove before } \\
\text { bed }\end{array}$ & $\begin{array}{l}\text { Headache, } \\
\text { cardiovasc } \\
\text { ular events, } \\
\text { asthenia, } \\
\text { dyspepsia, } \\
\text { myalgia, } \\
\text { and } \\
\text { vomiting }\end{array}$ & $\begin{array}{l}\text { Untill now, it } \\
\text { is not } \\
\text { approved by } \\
\text { any agency }\end{array}$ \\
\hline $\begin{array}{l}\text { Combined } \\
\text { Patch + } \\
\text { acute forms } \\
\text { (nicotine } \\
\text { gum, spray, } \\
\text { lozenge, \& } \\
\text { inhaler) }\end{array}$ & $\begin{array}{l}\text { Transdermal nicotine } \\
\text { doses of } 7,14 \text {, and } 21 \mathrm{mg}+ \\
\text { dosage of any one } \\
\text { acute form }\end{array}$ & $\begin{array}{l}\text { Nicotine dependence, } \\
\text { insomnia }\end{array}$ & $\begin{array}{l}\text { Both patch and acute } \\
\text { nicotine forms should } \\
\text { be used parallel. }\end{array}$ & $\begin{array}{l}\text { Mouth and } \\
\text { airway } \\
\text { irritation, } \\
\text { Nausea } \\
\text { and } \\
\text { vomiting }\end{array}$ & US FDA \\
\hline
\end{tabular}

*US FDA: U S Food and Drug Administration; MHRA: Medicines and Healthcare products Regulatory

Rx, Prescription; OTC, Over the counter

\section{How soon after waking do you smoke your first cigarette?}
a. Less than 5 minutes ( 3 points)
b. 5 to 30 minutes ( 2 points)
c. 31 to 60 minutes (1 point)
d. More than 60 minutes (no points)

\section{How many cigarettes do you smoke each day?}

a. More than 30 cigarettes ( 3 points)

b. 21 to 30 cigarettes ( 2 points)

c. 11 to 20 cigarettes ( 1 point) d. 1 to 10 cigarettes (no points)

\begin{tabular}{|ll|}
\hline Score & Nicotine dependence \\
\hline 5 or 6 & Heavy \\
\hline 3 or 4 & Moderate \\
\hline 2 & Low \\
\hline
\end{tabular}

Acute dosing is reached using gum, nasal spray, oral inhalers and tablets which helps in general craving relief with immediate release of nicotine whereas the transdermal patch acts slowly with sustained release. ${ }^{10,11}$ Different formulations have different levels of efficacy with different rates of nicotine absorption. But the psychiatric counseling has an additive effect along with this formulations (Table $3){ }^{12}$

Table 3 Guide for the selection of NRT product. $7,20,21,22$

\begin{tabular}{lll}
\hline Product & $\begin{array}{l}\text { Dosage } \\
\text { Heavy - moderate }\end{array}$ & $\begin{array}{l}\text { Dosage } \\
\text { Moderate }- \text { low }\end{array}$ \\
\hline Gum & $\begin{array}{l}4 \mathrm{mg} \text { (after the first } 2 \text { weeks you may prefer to use } \\
\text { the } 2 \mathrm{mg} \text { gum) }\end{array}$ & $\begin{array}{l}-2 \mathrm{mg} \\
- \text { Use I piece per hour or } 10-15 \text { pieces per day }\end{array}$ \\
Patch & $21 \mathrm{mg} / 24$ hour patch or $25 \mathrm{mg} / 16$ hour patch & $\begin{array}{l}-14 \mathrm{mg} / 24 \text { hour path } \\
- \text { Use I patch daily }\end{array}$ \\
Nicotine mouth spray & Maximum of 4 sprays an hour/ 64 sprays a day & $\begin{array}{l}\text { One or two sprays under the tongue or onto the } \\
\text { inner cheek to relieve cravings }\end{array}$ \\
\hline
\end{tabular}


Table Continued

\begin{tabular}{lll}
\hline Product & $\begin{array}{l}\text { Dosage } \\
\text { Heavy - moderate }\end{array}$ & $\begin{array}{l}\text { Dosage } \\
\text { Moderate - low }\end{array}$ \\
\hline Lozenge & $-4 \mathrm{mg}$ lozenge & 2mg lozenge or I.5mg lozenge \\
& $-4 \mathrm{mg} \& 2 \mathrm{mg}$ lozenges $(9-15$ per day $)$ & \\
& $-1.5 \mathrm{mg}$ lozenge $(9-20$ per day) & \\
& - I cartridge when you have urge to smoke or \\
Inhalation & - Fory $2-4$ hours \\
& $-25 \mathrm{mg} / \mathrm{I} 6$ hour patch in combination with $2 \mathrm{~g}$ gum \\
& or lozenge \\
& $-21 \mathrm{mg} / 24$ hour patch in combination with $2 \mathrm{mg}$ \\
& gum or $2 \mathrm{mg}$ or I.5mg lozenge \\
& - Patch in combination with any intermittent form \\
& of NRT
\end{tabular}

\section{Side effects of the NRT}

The symptoms of nicotine overdose includes nausea, salivation, abdominal pain, sweating, headache, and diarrhea, dizziness, delayed wound healing and weakness. ${ }^{25}$ At very high doses, it depresses neuronal activity whereas at low doses, it stimulates. ${ }^{23,24}$ It acute lethal dose of nicotine in $40-60 \mathrm{mg}^{25}$ and it can lead to death at $500 \mathrm{mg}$ or more dosages, due to generalized blockade of respiration. ${ }^{23}$ But, at the prescribed dosages of NRT, there was no evidence of any life threatening problems. ${ }^{25,26}$

Little caution is required while prescribing these NRT's in medically compromised patients like acute cardiovascular disease, pregnancy, or breast feeding. NRT is safe in stable cardiac disease, but caution is needed in unstable. ${ }^{8}$ It has been studied that the adverse effects of NRT during pregnancy has substantially lower risk compared to that of smoking. ${ }^{27}$

\section{Conclusion}

NRT is one of the best options as a treatment for all habit associated lesions in the oral cavity. Most of the lesions respond well by cessation of the habits. And NRT helps the patient to quit the habit. As an oral diagnostician, we have to motivate and educate the patient about the use of NRT. This article briefly describes the dosages, forms and side-effects of NRT.

\section{Acknowledgments}

None.

\section{Conflic of interest}

No conflict of interest declared.

\section{References}

1. Neville BW, Damm DD, Allen CM. Oral \& maxillofacial pathology. 2nd ed. Phila., PA: Saunders; 2002;337-369.

2. A guide for oral disease patients to quit tobacco use. Geneva: World Health Organization; 2017.

3. Foulds J, Burke M, Steinberg M, et al. Advances in pharmacotherapy for tobacco dependence. Expert OpinEmerg Drugs. 2004;9(1):39-53.

4. Kotlyar M, Hatsukami DK. Managing nicotine addiction. J Dent Educ. 2002;66(9):1061-1073.
5. Centers for Disease Control and Prevention (US), National Center for Chronic Disease Prevention and Health Promotion (US), Office on Smoking and Health (US). How Tobacco Smoke Causes Disease: The Biology and Behavioral Basis for Smoking-Attributable Disease: A Report of the Surgeon General. Atlanta (GA): Centers for Disease Control and Prevention (US); 2010.

6. Wadgave U, Nagesh L. Nicotine Replacement Therapy: An Overview. Int J Health Sci (Qassim). 2016;10(3):425-435.

7. Cancer council South Africa. Nicotine replacement therapy (NRT), 2016.

8. Molyneux A. ABC of smoking cessation. Nicotine replacement therapy BMJ. 2004;328(437):454-456.

9. Henningfield JE, Fant RV, Buchhalter AR, et al. Pharmacotherapy for nicotine dependence. CA Cancer J Clin. 2005;55(5):281-99.

10. Sweeney CT, Fant RV, Fagerstrom KO, et al. Combination nicotine replacement therapy for smoking cessation: rationale, efficacy and tolerability. CNS Drugs. 2001;15(6):453-467.

11. Fagerstrom KO. Combined use of nicotine replacement products. Health Values 1994;18:15-20.

12. A clinical practice guideline for treating tobacco use and dependence: A US Public Health Service report. The Tobacco Use and Dependence Clinical Practice Guideline Panel, Staff, and Consortium Representatives. JAMA. 2000;283(24):3244-3254.

13. Yildiz D. Nicotine, its metabolism and an overview of its biological effects. Toxicon. 2004;43(6):619-632.

14. Clinical Practice Guideline Treating Tobacco Use and Dependence 2008 Update Panel, Liaisons, and Staff. A clinical practice guideline for treating tobacco use and dependence: 2008 update. A U.S. Public Health Service report. Am J Prev Med. 2008;35(2):158-176.

15. Hajek P, Etter JF, Benowitz N, et al. Electronic cigarettes: review of use, content, safety, effects on smokers and potential for harm and benefit. Addiction. 2014;109(11):1801-1810.

16. Cantrell FL. Adverse effects of e-cigarette exposures. Journal of community health. 2014;39(3):614-616.

17. Brokowski L, Chen J, Tanner S. High-dose transdermal nicotine replacement for tobacco cessation. Am $J$ Health Syst Pharm. 2014.15;71(8):634-638.

18. Recommendations for Use of Combination Therapy in Tobacco Use Cessation.2016.

19. US Department of Veteran affairs. 2015. 
20. Action on Smoking and Health Australia. Guidelines for Healthcare Professionals on using Nicotine Replacement Therapy for smokers not yet ready to stop smoking. Sydney: Action on Smoking and Health Australia. 2007.

21. Zwar N, Richmond R, Borland R, et al. Smoking cessation pharmacotherapy: an update for health professionals. Melbourne: The Royal Australian College of General Practitioners. 2007, p. 16-18.

22. Zwar N, Richmond R, Borland R, et al. Smoking Cessation Guidelines for Australian General Practice. Practice Handbook. Canberra: Australian Government, Department of Health and Aging. 2004.

23. Meyer B. How much nicotine kills a human? Tracing back the generally accepted lethal dose to dubious self experiments in the nineteenth century. Arch Toxicol. 2014;88(1):5-7.
24. Karl F. Nicotine: Pharmacology, Toxicity and Therapeutic use. J Smok Cessat. 2014;9:53-59.

25. Lavelle C, Birek C, Scott DA. Are nicotine replacement strategies to facilitate smoking cessation safe? J Can Dent Assoc. 2003;69(9):592597.

26. Moore D, Aveyard P, Connock M, et al. Effectiveness and safety of nicotine replacement therapy assisted reduction to stop smoking: systematic review and meta-analysis. BMJ. 2009;2;338:b1024.

27. Osadchy A, Kazmin A, Koren G. Nicotine replacement therapy during pregnancy: recommended or not recommended? J Obstet Gynaecol Can. 2009;31(8):744-747. 